\title{
有明海奥部底泥における栄養塩フラックスの季節変化

\author{
Seasonal Variation of Nutrient Flux Between Sediments and Water Column \\ in the Inner Area of the Ariake Bay
}

\begin{abstract}
郡山益実 $^{1} \cdot$ 荒木啓輔 $^{2} \cdot$ 伊藤祐二 $^{3} \cdot$ 片野俊也 $^{4} \cdot$ 石谷哲寛 $^{5}$
Masumi KORIYAMA, Keisuke ARAKI, Yuji ITO, Toshiya KATANO and Tetsuhiro ISHITANI

The seasonal variation of nutrient flux between sediments and water column in the inner area of the Ariake Bay was investigated during May, 2010-November, 2011. The supply amount of organic matter to sea bottom and sediment temperature had important effects on the seasonal variation of $\mathrm{NH}_{4}{ }^{+}-\mathrm{N}$ concentration in porewater. The seasonal variation of $\mathrm{PO}_{4}{ }^{3-}-\mathrm{P}$ concentration in porewater was strongly dependent on those of redox environments in sediments. We found that the sediments were an important supply source of nutrient for the water column in the inner area of the Ariake Bay during summer-autumn. In the Porphyra aquaculture period, the phosphorus release from the sediments was thought to play an important role in the Porphyra production in the Ariake Bay.
\end{abstract}

\section{1. はじめに}

近年，有明海奥部では赤潮及び貧酸素水塊の大規模 化・頻発化や不安定なノリ生産などが大きな問題となっ ている (環境省，2006など)。このような海域の環境異 変には, 有明海における窒素やリンなどの栄養塩動態が 密接に関連していると考えられ, これまで海域の栄養塩 環境に関する幾つかの研究例が見られる。例えば, 渡辺 ら（2004）は，1972～2000年の浅海定線調査デー夕をも とに, 有明海奥部における栄養塩の平均濃度と現存量を 解析し, 秋〜冬季における海域の栄養塩供給には, 河川 以外の供給源が存在することを示唆した。また，速水ら （2009）と郡山ら（2009）は, 有明海奥部泥質干潟〜浅 海域における海水と底泥間隙水中の栄養塩濃度の季節変 化を明らかにし, 秋〜冬季における水柱栄養塩濃度の増 加は, 底泥からの栄養塩溶出が主要因であることを示唆 した.これらの研究は, 有明海奥部の栄養塩動態におい て底泥からの栄養塩供給の果たす役割の重要性を示すも のであるが, 底泥からの栄養塩溶出フラックスに関する 実測データの報告例は少なく, その季節変化は今だ十分 明らかにされていない.

本研究では, 有明海奥部に泥質と砂泥質の 2 地点に調 査区を設置し, 年間を通した現地調査及び栄養塩溶出実 験を行い, 底質内の物理環境や栄養塩濃度及び底質一海 水間の栄養塩フラックスの季節変化を明らかにする. 次 いで, 対象海域における底質からの栄養塩溶出量を定量 的に評価し, 海域の栄養塩変動における底質からの栄養

\begin{tabular}{lll}
\hline 1 正会員 & 博(農) & 佐賀大学助教農学部生物環境科学科 \\
2 & 農修 & 佐賀大学大学院農学研究科 \\
3 & 博(農) & 佐賀大学低平地沿岸海域センター \\
4 & 博(理) & 佐賀大学低平地沿岸海域センター \\
5 & 博(農) & 佐賀大学大学院農学研究科
\end{tabular}

塩供給の役割について検討, 考察することを目的とする.

\section{2. 現地調査及び分析の概要}

2010 年 5 月〜 2011 年 11 月に毎月 1 回，有明海奥部に設 定した泥質（St1）と砂泥質（St2）の2地点（図-1）で大 潮の満潮時に調査を実施した。現地調査は, 複数の底質 コア（内径 $56 \mathrm{~mm}$, 長さ $50 \mathrm{~cm}$ ) をダイバーによって採取 後, 直ちにサイフォンによりコア内から底質直上の海水 を採取した。そして，船上で底質コアを層別（表層〜 $2 \mathrm{~cm}$ は $1 \mathrm{~cm}$ 間隔及び $2 \sim 10 \mathrm{~cm}$ は $2 \mathrm{~cm}$ 間隔の計 6 層）に切 り分け, 各層の酸化還元電位（Eh）及び泥温を測定した. 残りの底質コアについては, 密栓して持ち帰り, 速やか に実験室において各層の底質サンプルを採取し, 水質及 び底質分析に供した。

底質間隙水は, 各層の底泥サンプルを遠心分離 $(4000$

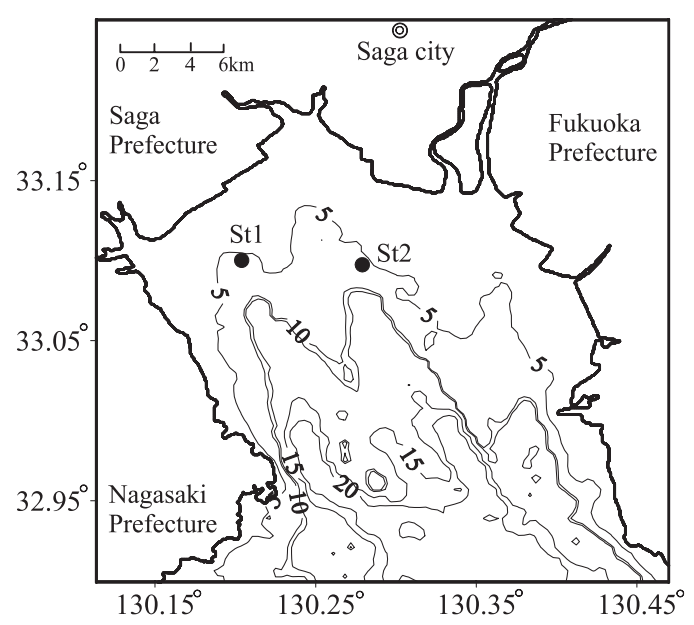

図-1 調査水域の海底地形と測点 
$\mathrm{rpm}$ で5分間）にかけ上澄み液を抽出した。抽出した上 澄み液は $0.45 \mu \mathrm{m}$ のメンブランフィルターで濾過し冷凍保 存した。底質直上水に関しても同様に $0.45 \mu \mathrm{m}$ のメンブラ ンフィルターで滤過し冷凍保存した。後日, これらを解 凍しオートアナライザー（SWAAT, BLTEC）を用いて $\mathrm{NH}_{4}{ }^{+}-\mathrm{N}, \mathrm{NO}_{3}{ }^{-}-\mathrm{N}, \mathrm{NO}_{2}^{-}-\mathrm{N}$ 及び $\mathrm{PO}_{4}{ }^{3-}-\mathrm{P}$ 濃度の定量分析を 行った.

底質は, 含泥率, 含水率, 有機態炭素 (TOC) 及び全 窒素（TN）の分析を行った。ここで，底質中の TOCの 前処理として，採取した底質試料を乾燥後メノウ乳鉢で 磨砕し，1Nの HCl 添加して試料中の炭酸カルシウムを 処理した。前処理した底質の TOC及びTNの測定は, CHNコーダ（JM-10，J-Science LAB）を用いて分析を行 った。

栄養塩の溶出実験は，小野澤ら（2007）の方法に準じ て行った.すなわち, 現地で採取した底質コアと海水を それぞれ冷蔵状態で実験室に持ち帰り，速やかに実験を 開始した，実験は，まず底質が巻き上がらないように滤 過した現地海水を注意深くコア内に注入した後，現地泥 温に設定した恒温室内の培養水槽に静置した。そして, 実験開始時，4，6，8 及び 24 時間後の底質コア直上水を 採水し, 直上水における栄養塩濃度 $\left(\mathrm{NH}_{4}{ }^{+}-\mathrm{N}, \mathrm{NO}_{3}{ }^{-}-\mathrm{N}\right.$, $\left.\mathrm{NO}_{2}{ }^{-}-\mathrm{N}, \mathrm{PO}_{4}{ }^{3-}-\mathrm{P}\right)$ をオートアナライザーで分析した。な お，溶出実験中は，攪拌機を用いて底質が巻き上がらな いように直上水を十分攪汼, 混合し, 恒温室内を暗条件 とした.

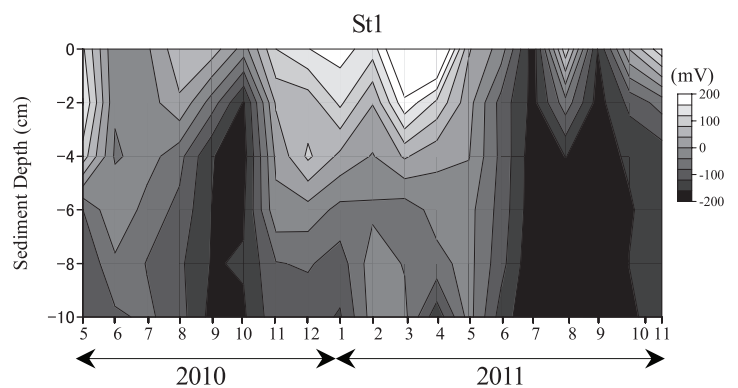

\section{3. 結果及び考察}

\section{（1）底質環境}

図-2 及び3 は, St 1 及び St 2 における底質 $\mathrm{Eh}$ の鉛直分布 と底質 TOC及びTNの季節変化を表したものである。な お，ここで底質 TOC及びTNは底質表層〜 $10 \mathrm{~cm}$ の平均值 である. 図示されるように，2010年の場合，St1におけ る底質のEhは，6月から徐々に低下し，7～10月の底質 は全体的に $-43.2 \sim-141.0 \mathrm{mV}$ （表層〜 $10 \mathrm{~cm}$ の平均值） と還元的状態の層が卓越した。そとて，11月以降，底質 は表層部から酸化的層が徐々に拡大し，冬〜春季におい て底質の $\mathrm{Eh} は+9.8 〜+63.9 \mathrm{mV}$ とほほ酸化的状態の層に遷 移した。2011年の場合，St1の底質は6月にはすでに還元 的層になっており $(\mathrm{Eh}=-90.3 \mathrm{mV})$, この還元的層は 11 月まで継続して見られた $(\mathrm{Eh}=-79.1 \sim-187.4 \mathrm{mV})$. また，2011年の夏〜秋季における $\mathrm{Eh}$ の平均值 $(\mathrm{Eh}=-$ $139.5 \mathrm{mV})$ は，2010年のそれ $(\mathrm{Eh}=-76.2 \mathrm{mV})$ と比較し て大きく低下し，St1の底質はより還元的状態であった。 一方, St2の底質の酸化還元環境は, St 1 と同様の季節変 化を示すが, St1 ほどの夏〜秋季における底質の還元化 は見られなかった。

調査期間を通して St1 と St2における底質 TOC及びTN は，いずれも統計的に有意な差が見られ，St1のTOC及 びTNはSt2のそれらより約 2.4 倍高かった。これは両地 点における含泥率の差異を反映したためである。すなわ ち，St1の含泥率は年間を通して $86.2 〜 98.6 \%$ を推移する

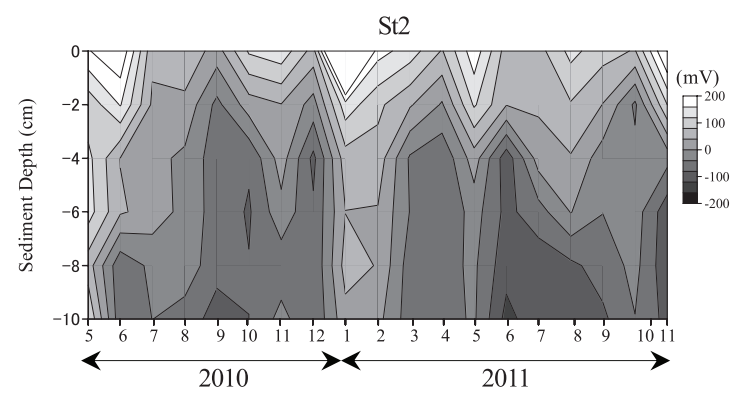

図-2 St1 及びSt2における底質 $\mathrm{Eh}$ の鉛直分布
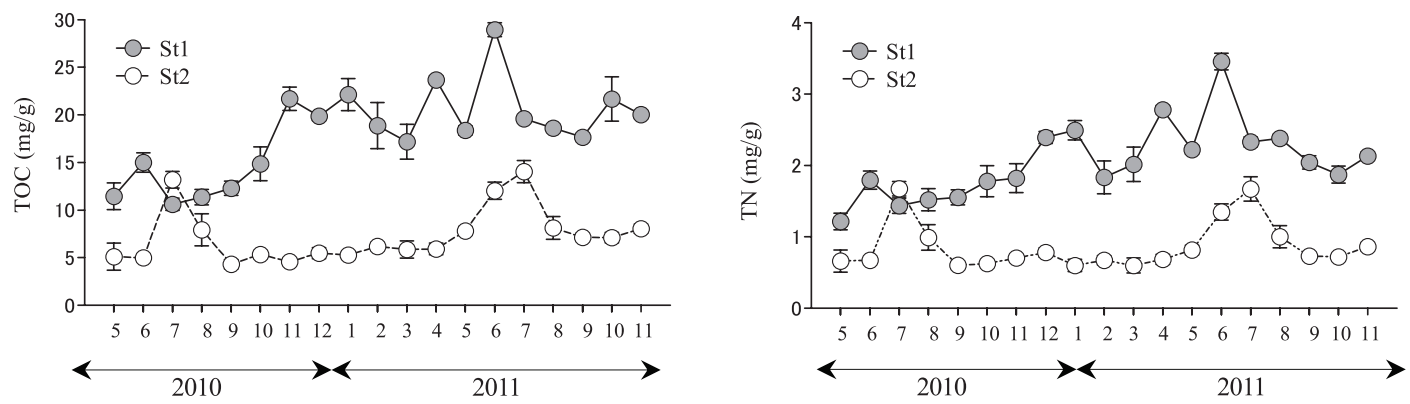

図-3 St1 及びSt2における底質 TOC及びTNの季節変化 
のに対し，St2は出水期を除き $21.8 〜 46.3 \%$ 範囲で変動 し, St1の含泥率がSt2のそれより高いためである.

また, St1のTOC及びTNは, 出水期（2010年6月, 2011 年 6 月）とノリ養殖期（2010年 11月～2011年 1月） に増加する季節変化を示した。 これは, 出水やノリ養殖 により海底への有機物供給量が増加したためと考えられ

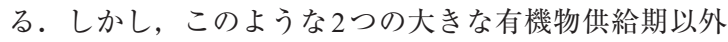
に，2011年4月にSt1の TOCと TNは増加した。この原因 については今のところ不明である. 今後, 海底面の侵 食・堆積状況の連続モニタリング等により原因を明らか にする必要がある。一方, St2のTOC及び TNは, 出水期 に増加するが, それ以外の期間はそれぞれ $5.36 \mathrm{mg} / \mathrm{g}$ 及び $0.66 \mathrm{mg} / \mathrm{g}$ 前後を推移した. この出水期における TOC及び $\mathrm{TN}$ の増加は, 出水に伴って微細な土粒子が海底に堆積 し, 含泥率が81.0～94.7\% と大きく増加したためである. このことから, St2の底質は出水期における微細土粒子 の堆積量に大きく左右されるものと考えられる.

\section{（2）底質間隙水中の栄養塩濃度}

図-4 は, St1 及び St2 における底質間隙水中の $\mathrm{NH}_{4}{ }^{+}-\mathrm{N}$, $\mathrm{NO}_{3}{ }^{-}-\mathrm{N}$ 及び $\mathrm{PO}_{4}{ }^{3-}-\mathrm{P}$ 濃度の季節変化を表したものである. なお，これらの值は，表層〜 $10 \mathrm{~cm}$ の平均值である. 両 地点共に $\mathrm{NH}_{4}{ }^{+}-\mathrm{N}$ 濃度は夏〜秋季に増加し, 冬季に減少し た.しかし, 両地点の $\mathrm{NH}_{4}{ }^{+}-\mathrm{N}$ 濃度の間には統計的に有意 な差があり, $\mathrm{St} 1$ の $\mathrm{NH}_{4}{ }^{+}-\mathrm{N}$ 濃度は平均して St2のそれの約 3.4 倍高かった。また, St1の2011年夏〜秋季における $\mathrm{NH}_{4}{ }^{+}-\mathrm{N}$ 濃度は, 2010年のそれの約 1.6 倍高かった。この ような地点間や経年的な $\mathrm{NH}_{4}{ }^{+}-\mathrm{N}$ 濃度の差異は, 底質有機 物量と密接に関連するものと考えられる. すなわち, 表1 に示されるように, 地点間の $\mathrm{NH}_{4}{ }^{+}-\mathrm{N}$ 濃度差は, 主に底 質 (含泥率) の違いによる有機物含有量の大小によるも のと考えられる.また，2011年夏〜秋季の $\mathrm{NH}_{4}{ }^{+}-\mathrm{N}$ 濃度 が2010年のそれより高い原因の $1 つ に ， 2010$ 年と比較し て底質有機物量が約 1.6 倍増加したため, 有機物の分 解・無機化により生成された $\mathrm{NH}_{4}{ }^{+}$が底泥内に多く集積し たためと考えられる。このことから, 底質間隙水中の $\mathrm{NH}_{4}{ }^{+}-\mathrm{N}$ 濃度の変動は, 基本的には底質有機物量と泥温に 依存していると推察される.

$\mathrm{NO}_{3}^{-}-\mathrm{N}$ 濃度は, 両地点共に始め 5 月に高く, その後減 少し6〜11月は低濃度であるが $(0.4 〜 2.4 \mu \mathrm{mol} / 1), 11$ 月 以降増加し， 3〜4月に5.9〜 7.7 $\mu \mathrm{mol} / 1$ と大きく増加した.
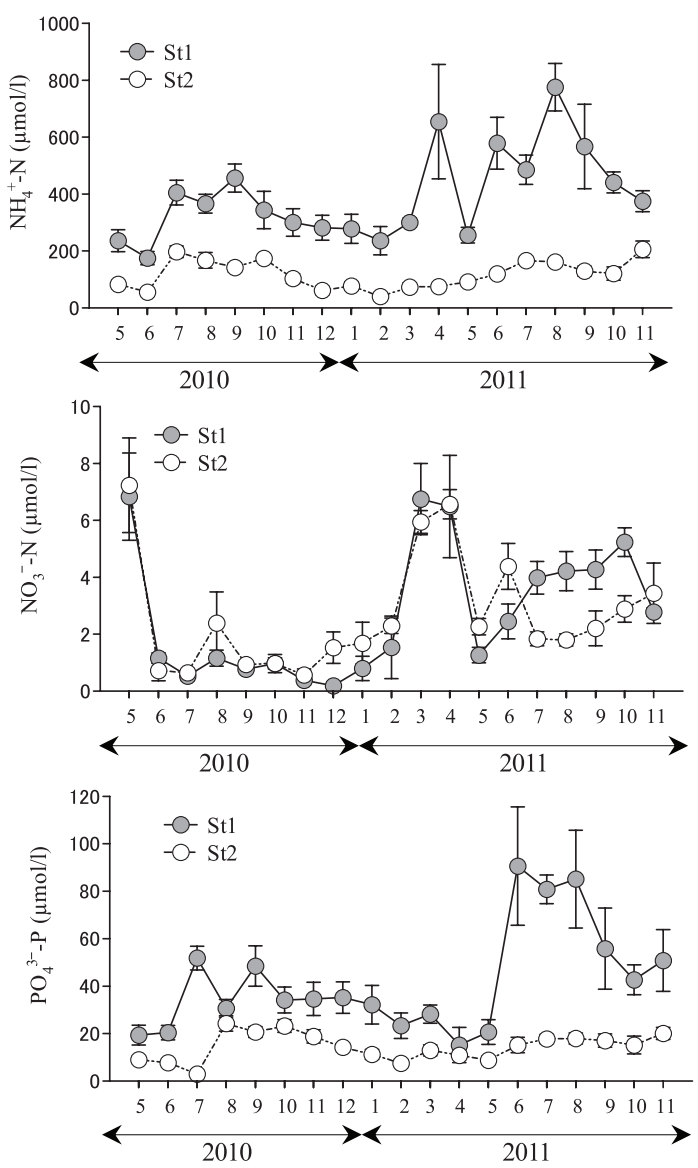

図-4 St1 及びSt2における底質間隙水中の栄養塩濃度 $\left(\mathrm{NH}_{4}{ }^{+}-\mathrm{N}, \mathrm{NO}_{3}{ }^{-}-\mathrm{N}, \mathrm{PO}_{4}{ }^{3-}-\mathrm{P}\right)$ の季節変化

この2010年夏〜秋季における $\mathrm{NO}_{3}^{-}-\mathrm{N}$ の低濃度は, 底質 が還元的状態であるため，底質内で硝化が抑制されてい たことに加え, 脱窒により大部分の $\mathrm{NO}_{3}{ }^{-}$が消費されたた めと考えられる. また， 3〜4月における $\mathrm{NO}_{3}^{-}-\mathrm{N}$ 濃度は $\mathrm{NO}_{2}{ }^{-}-\mathrm{N}$ 濃度の増加後に遅れて増大することから, 底質表 層部の酸化的層の発達に伴い硝化が促進され $\mathrm{NO}_{3}{ }^{-}$が集積 されたためと考えられる.しかし，2011年夏〜秋季にお ける $\mathrm{NO}_{3}^{-}-\mathrm{N}$ 濃度は, $\mathrm{St} 1$ において底質がより還元的環境 であるにもかかわらず, $2.4 \sim 5.2 \mu \mathrm{mol} / 1$ と比較的高い濃 度を示した。この原因は今のところ不明であるが，2011 年は出水期以降多雨であったため, 河川流入量が平年よ り多く, 海水中の $\mathrm{NO}_{3}{ }^{-}-\mathrm{N}$ 濃度が高かったことが影響して

表-1 底質間隙水中の $\mathrm{NH}_{4}{ }^{+}-\mathrm{N}$ 濃度と底質 $\mathrm{TOC}, \mathrm{TN}$ 及び含泥率

\begin{tabular}{l|cccc}
\hline \multicolumn{1}{c|}{ Period (Station) } & $\mathrm{NH}_{4^{+}}-\mathrm{N}(\mu \mathrm{mol} / \mathrm{l})$ & $\mathrm{TOC}(\mathrm{mg} / \mathrm{g})$ & $\mathrm{TN}(\mathrm{mg} / \mathrm{g})$ & Mud content $(\%)$ \\
\hline May, 2010-November, 2011 (St1) & $395.04 \pm 154.93$ & $18.28 \pm 4.70$ & $2.06 \pm 0.51$ & $94.15 \pm 3.49$ \\
\hline May, 2010-November, 2011 (St2) & $117.69 \pm 48.95$ & $7.28 \pm 2.79$ & $0.86 \pm 0.33$ & $47.32 \pm 18.79$ \\
\hline June-October, 2010 (St1) & $349.04 \pm 95.05$ & $12.81 \pm 1.81$ & $1.62 \pm 0.14$ & $90.97 \pm 4.31$ \\
\hline June-October, 2011 (St1) & $569.31 \pm 115.06$ & $21.29 \pm 4.06$ & $2.42 \pm 0.55$ & $97.22 \pm 1.50$ \\
\hline
\end{tabular}


いるものと考えられる．すなわち，2011年 8～10月にお ける筑後川日流量は平均約 $147.7 \mathrm{~m}^{3} / \mathrm{s}$ であり（2010年の約 1.6 倍), 海水中の $\mathrm{NO}_{3}-\mathrm{N}$ 濃度は3.8 $8.8 \mu \mathrm{mol} / 1$ と比較的 高濃度であった。このため, 海水から底泥への $\mathrm{NO}_{3}$-の取 り込みが活発に行われ，脱窒による $\mathrm{NO}_{3}$-消費を差し引い た $\mathrm{NO}_{3}$ `が底泥内に集積した結果，St1において夏〜秋季 に $\mathrm{NO}_{3}-\mathrm{N}$ 濃度が高くなったものと推察される。

両地点に抢ける $\mathrm{PO}_{4}{ }^{3-}-\mathrm{P}$ 濃度の差異や季節変化は, 底質 の酸化還元環境の変動と密接に関連した（図-2)。すなわ ち，夏一秋季の底質は全体的に還元的層であるため，水 酸化第二鉄に吸着していたリンがイオン化し, 間隙水中 の $\mathrm{PO}_{4}{ }^{3}-\mathrm{P}$ 濃度が増加する。しかし, 冬〜春季の底質表層 部は酸化的状態であるため, 間隙水中の第一鉄イオンが 酸化されることにより生じる水酸化第二鉄にリンが吸着 され, 間隙水中の $\mathrm{PO}_{4}^{3-}-\mathrm{P}$ 濃度が減少するものと考えられ る(郡山ら，2009）。したがって，St1は夏〜秋季に底質 のEhが大きく低下し，底質の有機物含有量が高いため $\mathrm{St} 2$ より $\mathrm{PO}_{4}{ }^{3-}-\mathrm{P}$ 濃度が高くなり，また，顕著な底質の還 元化が見られる2011年夏〜秋季に $\mathrm{St} 1$ の $\mathrm{PO}_{4}{ }^{3-}-\mathrm{P}$ 濃度が大 きく増加するものと考えられる.

（3）底質-水柱間の栄養塩フラックス

図-5は，栄養塩溶出実験より得られた $\mathrm{NH}_{4}^{+}-\mathrm{N}, \mathrm{NO}_{3}^{-}-\mathrm{N}$, $\mathrm{NO}_{2}-\mathrm{N}, \mathrm{PO}_{4}^{3-}-\mathrm{P}$ の溶出速度 $\left(J_{\mathrm{NH} 4}, J_{\mathrm{NO} 3}, J_{\mathrm{NO} 2}, J_{\mathrm{PO} 4}\right)$ の 季節変化を表したものである.ここで, 溶出速度が正の 場合，底質から水柱への溶出を，負の場合，水柱から底 質への取り込みを示している．図示されるように， $J_{\mathrm{NH} 4}$ は両地点共に夏〜秋季に増加，冬季に減少する季節変化 を示し，年間を通して $\mathrm{NH}_{4}{ }^{+}$は底質から溶出した。また， $\mathrm{St} 1$ の $J_{\mathrm{NH} 4}$ は, 調查期間を通して St2 の平均約 6 倍高い值 を示し (St1:5.39 $\mathrm{mmol} \mathrm{m}^{-2} \mathrm{~d}^{-1}$, St2: 0.90 $\left.\mathrm{mmol} \mathrm{m}^{-2} \mathrm{~d}^{-1}\right)$, 特に, 2011 年夏〜秋季では $3.2 \sim 21.5 \mathrm{mmol} \mathrm{m}^{-2} \mathrm{~d}^{-1}$ と大きく増加 した.このような地点別あるいは経年的な $J_{\mathrm{NH} 4}$ の変動は,
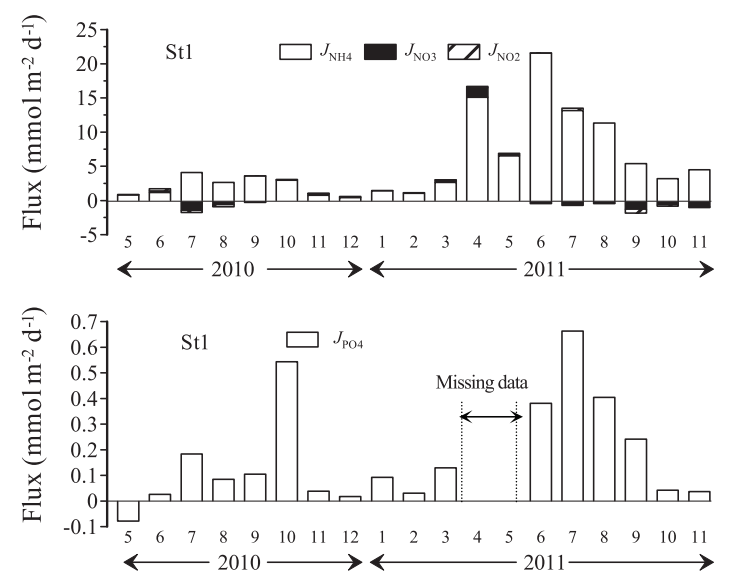

底質間隙水の $\mathrm{NH}_{4}{ }^{+}-\mathrm{N}$ 濃度の変動と概ね対応し, 間隙水 $\mathrm{NH}_{4}{ }^{+}-\mathrm{N}$ 濃度の増加に伴い $J_{\mathrm{NH} 4}$ も増大した（図-6). この ことから， $J_{\mathrm{NH} 4}$ は間隙水 $\mathrm{NH}_{4}{ }^{+}-\mathrm{N}$ 濃度と密接に関連し，基 本的には海底への有機物供給量と泥温に支配されるもの と推察される。また， $J_{\mathrm{NH} 4}$ のDIN フラックスに占める割 合は，両地点共に調查期間を通して約 6〜9割であった.

St 2 に扮ける $J_{\mathrm{NO} 3}$ は，夏季に $-0.11 \sim-0.38 \mathrm{mmol} \mathrm{m}^{-2} \mathrm{~d}^{-1}$ と底質への $\mathrm{NO}_{3}^{-}$-の取り达从を示すが，それ以外の期間は 底質から $\mathrm{NO}_{3}$-の溶出を示した。一方，St1に扔ける $J_{\mathrm{NO} 3}$

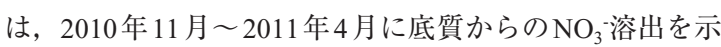
すが，それ以外の期間は底質への $\mathrm{NO}_{3}$-の取り込みを示し た. 特に，2011年6〜 10月における $J_{\mathrm{NO} O}$ は平均 $-0.57 \mathrm{mmol}$ $\mathrm{m}^{-2} \mathrm{~d}^{-1}$ であり, 2010 年の同時期のそれ（平均 $-0.34 \mathrm{mmol}$ $\left.\mathrm{m}^{-2} \mathrm{~d}^{-1}\right)$ と比較して約 1.7 倍高く, 水柱から底質への $\mathrm{NO}_{3}^{-}$ の取り込みが活発であった。 そこで, St1の脱窒速度を 有明海奥部泥質干潟で得られた夏〜秋季の平均的な脱窒 速度 $\left(0.29 \mathrm{mmol} \mathrm{m}^{-2} \mathrm{~d}^{-1}\right)$ （古賀ら，2009）と見なした場合, 2010年6〜10月に取り込まれた $\mathrm{NO}_{3}$-の約 $85 \%$ は脱窒によ り消費されるが，2011年では取り込まれた $\mathrm{NO}_{3}^{-}$の約 $41 \%$ が底泥内に蓄積する結果となった。このことから， St1 おいて底質が強い還元的環境であるにも関わらず2011年 夏〜秋季の底質間隙水中の $\mathrm{NO}_{3}^{-}-\mathrm{N}$ 濃度が高い原因の 1 つ に, 海水から底質への $\mathrm{NO}_{3}-$ - 取り达みが活発に行われ, 底質への $\mathrm{NO}_{3}$-供給量が増加したことが考えられる。

$J_{\mathrm{PO} 4}$ は $J_{\mathrm{NH} 4}$ と同様の季節変化を示し, 両地点共に夏〜 秋季に増加し, 冬季に低下した。また, St1の $J_{\mathrm{PO} 4}$ は調査 期間を通して St2の約 4 倍高く（St1：0.22 $\mathrm{mmol} \mathrm{m}^{-2} \mathrm{~d}^{-1}$, St2 : $\left.0.06 \mathrm{mmol} \mathrm{m}^{-2} \mathrm{~d}^{-1}\right)$, 特に, 底質の還元化が顕著で間 隙水 $\mathrm{PO}_{4}{ }^{3}-\mathrm{P}$ 濃度が急増する 2011 年夏〜秋季に $0.24 \sim 0.66$ $\mathrm{mmol} \mathrm{m} \mathrm{d}^{-2}$ と大きく増加した。 このことから， $J_{\mathrm{PO} 4}$ の変 動は, $J_{\mathrm{NH} 4}$ と同様に底質間隙水の $\mathrm{PO}_{4}{ }^{3-}-\mathrm{P}$ 濃度と密接に関 連し, 基本的には底質の酸化還元環境の変化に大きく影
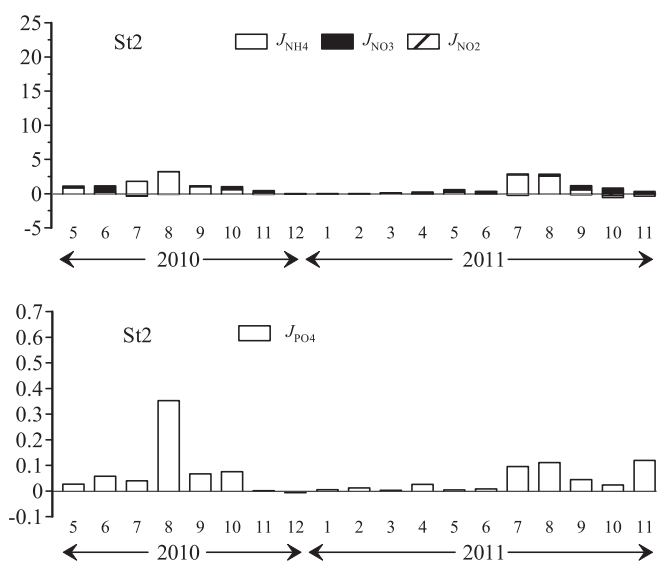

図-5 St 1 及びSt2における底質一水柱間の栄養塩フラックスの季節変化 


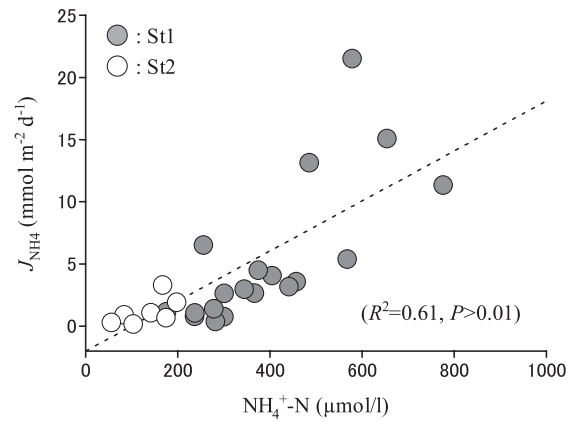

図-6 底質間隙水中の $\mathrm{NH}_{4}{ }^{+}-\mathrm{N}$ 濃度 (底質表層 $10 \mathrm{~cm}$ の平均值) と $\mathrm{NH}_{4}{ }^{+}-\mathrm{N}$ 溶出速度 $\left(J_{\mathrm{NH} 4}\right)$ との関係

響されるものと推察される.

図-7は，有明海奥部海底からの DIN及び $\mathrm{PO}_{4}{ }^{3-}-\mathrm{P}$ の総溶 出量 $\left(L_{\mathrm{DIN}}, L_{\mathrm{PO} 4}\right)$ と筑後川からの DIN及び $\mathrm{PO}_{4}{ }^{3-}-\mathrm{P}$ の供 給量 $\left(R_{\mathrm{DIN}}, R_{\mathrm{PO} 4}\right)$ の季節変化を表したものである.こ こで, $L_{\mathrm{DIN}}$ 及び $L_{\mathrm{PO} 4}$ は, 本研究で得られた栄養塩フラッ クスと St 1 及び $\mathrm{St} 2$ に対応する含泥率 85 ～100\% 及び 25 $40 \%$ の有明海奥部における海底面積より算出した。

また， $R_{\mathrm{DIN}}$ 及び $R_{\mathrm{PO} 4}$ は，調査期間における筑後川（瀬 ノ下）の日平均流量（速報值）を用いて，瀬ノ下で得ら れた L-Q式（山本，私信）より算出した. 図示されるよ うに, 出水期以降の $8 \sim 10$ 月における $L_{\mathrm{DIN}}$ 及び $L_{\mathrm{PO} 4}$ は, それぞれ9.06 \pm 6.81 ton $\mathrm{d}^{-1}$ 及び $1.17 \pm 0.80$ ton $\mathrm{d}^{-1}$ であった. 一方，同期間における $R_{\mathrm{DIN}}$ 及び $R_{\mathrm{PO} 4}$ は，それぞれ $7.74 \pm$ 2.25 ton $\mathrm{d}^{-1}$ 及び $0.37 \pm 0.35$ ton $\mathrm{d}^{-1}$ であることから, 出水期 以降の夏〜秋季において河川から供給される同程度の $\mathrm{DIN}$ と 3 倍近い $\mathrm{PO}_{4}{ }^{3-}-\mathrm{P}$ が海底から溶出することが示され た.したがって，夏〜秋季における海底からの栄養塩溶 出は, 海水中への重要な栄養塩供給源の1つであり, 秋 季の水柱内栄養塩動態に及ぼす影響は大きいものと考え られる。また，ノリ養殖期（11〜3月）における $L_{\mathrm{DIN}}$ 及 び $L_{\mathrm{PO} 4}$ は，それぞれ $2.92 \pm 1.83$ ton $^{-1}$ 及び $0.28 \pm 0.22$ ton

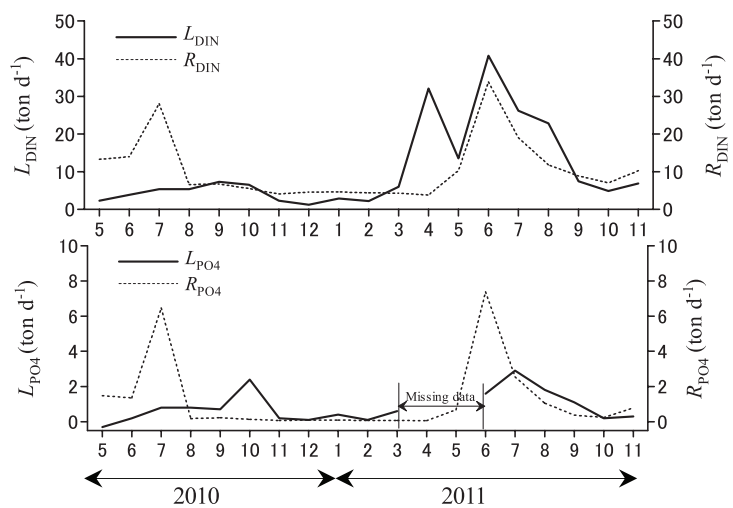

図-7 有明海奥部における $L_{\mathrm{DIN}}$ 及び $L_{\mathrm{PO} 4}$ と筑後川からの $R_{\mathrm{DIN}}$ と $R_{\mathrm{PO} 4}$ の季節変化 $\mathrm{d}^{-1}$ であった。 これは，それぞれ $R_{\mathrm{DIN}}$ 及び $R_{\mathrm{PO} 4}$ の $67 \%$ 及び $341 \%$ に相当する DIN と $\mathrm{PO}_{4}{ }^{3-}-\mathrm{P}$ が海底から溶出したこと を示しており，このことから，ノリ養殖期において海底 は特にリンの重要な供給源の1つであることが明らかに された。

\section{5. まとめ}

本研究によって得られた主な知見は, 以下のように要 約される。

（1）両地点における底質間隙水中の $\mathrm{NH}_{4}{ }^{+}-\mathrm{N}$ と $\mathrm{PO}_{4}{ }^{3-}-\mathrm{P}$ 濃 度は, 夏〜秋季に増加し, 冬季に減少する季節変化を 示した。これは, 基本的に前者は泥温と底質有機物量 の変動が, 後者は底質の酸化還元環境の変動が大きく 影響するものと考えられた。

（2）両地点における底質間隙水中の $\mathrm{NO}_{3}{ }^{-}-\mathrm{N}$ 濃度は，2010 年夏〜秋季において低濃度であったが，底質の還元化 が顕著な 2011 年夏〜秋季の St1において比較的高濃度 であった。この原因の 1 つに海水から底質への活発な $\mathrm{NO}_{3}^{-}$の取り込みが考えられた。

(3) 栄養塩溶出実験より得られた $J_{\mathrm{NH} 4}$ 及び $J_{\mathrm{PO} 4}$ は，夏〜 秋季に高く，冬〜春季に低くなる季節変化を示し， DIN フラックスに占める $J_{\mathrm{NH} 4}$ の割合は 6〜9割であっ た。また，出水期以降の夏〜秋季における $L_{\mathrm{DIN}}$ は $R_{\mathrm{DIN}}$ と同程度, $L_{\mathrm{PO} 4}$ は $R_{\mathrm{PO} 4}$ の約 3 倍であり, 海底は夏〜秋季 において重要な窒素とリンの供給源であることが明ら かにされた。また，ノリ養殖期における $L_{\mathrm{PO} 4}$ は $R_{\mathrm{PO} 4}$ の 約 3.4 倍と高いことから，ノリ生産にとって海底からの リンの供給は重要な役割を果たすものと考えられた。

謝辞：本研究を実施するに際し, 佐賀大学低平地沿岸海 域研究センター有明海研究プロジェクトより, 多大な支 援を受けた。

\section{参 考 文 献}

速水祐一 - 山本 浩一 - 濱田孝治 - 郡山益実 - 古賀あかね 吉野健児・吉田 誠・片野俊也・山口創一（2009）：有明 海奥部に打ける栄養塩濃度分布の季節変化, 土木学会論 文集B2（海岸工学）, Vol.65, No.1, pp.991-995.

環境省 (2006): 有明海・八代海総合調査評価委員会報告, $85 \mathrm{p}$. 郡山益実・瀬口昌洋 - 古賀あかね・アリム イスナンセテ ヨ・速水祐一・山本浩一・濱田孝治・吉野健児 (2009)： 有明海奥部の干潟・浅海域底泥における窒素・リンの季 節変化, 土木学会論文集 B2 (海岸工学), Vol.65, No.1, pp.1031-1035.

古賀あかね・瀬口昌洋・郡山益実（2009）：有明海奥部干潟域 における脱窒菌群の生息分布と脱窒活性, 農業農村工学 会論文集，第260号，pp.15-22.

小野澤恵一 一鯉㴊幸生・阿部哲也 - 寺田一美 - 磯部雅彦 (2007): 有明海奥部における栄養塩溶出フラックスの時空 間変動，海岸工学論文集，54，pp.1116-1120。

渡辺康憲・川村嘉応・半田亮司 (2004) : ノリ養殖と栄養塩ダ イナミックス, 沿岸海洋研究, 42 巻, 1号, pp.47-54. 